\title{
Understanding the Relationship between School-Based Management, Emotional Intelligence and Performance of Religious Upper Secondary School Principals in Banten Province
}

\author{
Oleh Eneng Muslihah ${ }^{1}$ \\ ${ }^{1}$ Lecture IAIN Sultan Maulana Hasanuddin Banten, Indonesia \\ Correspondence: Eneng Muslihah, IAIN Sultan Maulana Hasanuddin Banten Jl. Jenderal Sudirman No. 30 \\ Serang Banten, Indonesia. E-mail: e.muslihah01@gmail.com
}

Received: April 20, 2015

Accepted: April 22, 2015

Online Published: May 25, 2015

doi:10.5539/hes.v5n3p11

URL: http://dx.doi.org/10.5539/hes.v5n3p11

\begin{abstract}
The research examines the correlation between the understanding of school-based management, emotional intelligences and headmaster performance. Data was collectred, using quantitative methods. The statistical analysis used was the Pearson Correlation, and multivariate regression analysis. The results of this research suggest firstly that there is significant correlation between understanding of school-based management and principals performance. Secondly, there is a significan correlation between emotional intelligences and principals performance. Thirdly, there is a significant correlation between the understanding of school-based management, emotional intelligence and principals performance.
\end{abstract}

Keyword: principals performance, understanding of school-based management, emotional intelligences

\section{Introduction}

The success of education at upper secondary school level, especially Islamic schools (Islamic Senior High School) is influenced by many factors ranging from human resources such as school principals, students, school building, library, classroom equipment and the like. The school principal is the main role and determinants (determinant) success in organizing the school to improve student academic achievement and skills. Principals have the authority in the administration of the school. Her role as an educator, manager, administrator, supervisor, manager, innovator, and motivator (Mulyasa, 2003).

The success of school leaders to drive the effectiveness of a school is often linked to the quality of school leadership (Isaac, 2002; Awang \& Ramaiah, 2002; Karim, 1989). In the context of improving the performance and promoting excellence in education, particularly in religious schools, school leaders are not only viewed in terms of their stability or strength of style, but also in terms of their quality of motivation, empathy, integrity and intuitive ability, all of which are a part of emotional intelligence (Lunenberg \& Ornstein, 2004).

To improve performance, the school organization has developed school-based management. Implemantation School-Based Management in the school and its application in the field include: 1) Management of curriculum and learning programs, 2) Management of educators, 3) student management, 4) financial management, 5) Management of educational facilities, 6) Relationship management school with the public, and special services management (Mulyasa, 2002).

The success of the organization work of the school depends on how the working group, which means the work can be carried out in accordance with the values, ideology, religion, tradition, technology owned by the human resources are concerned. From the point of emotional intelligence has found that school principals act less intelligent, like angry against teachers, staff and students without apparent reasons. Have no feeling for others as yet can feel the happiness and suffering of other schools, less sensitive to the situation, can not control themselves and tend to act emotionally. Principals are less able to develop their emotional intelligence abilities to the maximum that can give you happiness, pleasure and joy to the students at school.

According to Goleman, Boyatzis and McKee (2004), the greatness of a leader depends on his or her ability to understand the emotional state of their subordinates in the workplace. The ability to manage emotions is called emotional intelligence. Thus, it is recognized that the better a principal is at controlling his emotions, the better 
the performance of the principal of the school. Research literature suggests that emotional competence is impacting the next leadership to subordinate role in enhancing the effectiveness of an organization (Hamlin, 2003; Zehner \& Holton III, 2003).

Goleman (2005), states that leaders who have the power of emotions is a good leader who can lead and be able to take care of subordinated. This is because the ability to understand the emotional leader subordinate is something quite important in the workplace. In this case, build strength in emotional intelligence is the strength of leadership in all levels of the organization (Covey, 2004).

The aim of this study is basically meant to get an idea of how big the school-based management, emotional intelligence and school principals performance, relationship and contribution confirmation understanding school-based management and headmaster performance, emotional intelligences and headmaster performance and understanding of school-based management, emotional intelegence and headmaster performance at State Religious School Banten Indonesia.

\section{Literature Review}

\subsection{Understanding of School-Based Management}

One of which must be understood by the school principal is the school-based management. School-Based Management (SBM) is a strategy to create an effective and productive school. School-based management is one of the existence of educational reform that gives autonomy to schools to organize life according to their potential, demands, and requirements.

Mulyasa (2003) the concept of School-Based Management (SBM) to power the schools include decisions about curriculum and learning management; recruitment and management of education personnel; and financial management of the school. School-Based Management (SBM) is an idea about making decisions that placed education at the state closest to learning, i.e. school. Empowerment schools by giving greater autonomy, in addition to providing a good service to the needs of their community in education effectiveness, quality and so on.

School-based management model is a model school for school-based management in Malaysia Rahmad Syukor Abd Samad (1997), adapted from the Cheng (1993). This model consists of six key elements are: the mission of the school, startegic management, decision-making styles, use of resources, the quality of the administrator, and the role of each element in school (Samad, 2003).

In the School-Based Management system, the school has "full authority and responsibility" in establishing educational programs and policies in accordance with the vision, mission, and goals (Mohrman \& Wihlsetter, 1994). Characteristics of School-Based Management (SBM) may be unknown among others of how schools can optimize achievement, learning process, learning resource management, professionalism of staff, as well as the overall management system. School-Based Management has the potential to support a new paradigm of management education in the context of regional autonomy and decentralization of education in Indonesia, in accordance with Law No. 22/1999, Government Regulation No. 25/2000, and Act No. 20 of 2003 on National Education System.

\subsection{Emotional Intelligence}

Goleman (1999) defines emotional intelligence as: The ability to recognize our own feelings and the feelings of others, ability to motivate yourself, and the ability to manage emotional well in ourselves and in association with others. Emotional intelligence possessed by humans is very useful for human life itself is a journey full of obstacles. Human emotional intelligence through a "confidence" in creating a good body condition. With confidence can be one of the important therapies in creating a balanced state of body. In other words optimism and positive thinking provide beneficial effects in the human body condition (Pasiak, 2002).

Emotional intelligence requires skills that can form habits that are useful in achieving personal success. Managing emotions requires discipline, personal motivation and self-awareness. Theory of emotional intelligence is relied Bar-On model Emtional quetion Inventroy and Bar-On Version ole and James Parker. Bar-On model based on this intelligence include cognitive intelligence as measured by the IQ and emotional intelligence as measured by the EQ, an individual who works well, successful and healthy emotion is a person who has sufficient emotional tendencies.

Emotional intelligence can develop from time to time, change throughout life, and can be enhanced through training, rehabilitation programs and therapeutic interventions. Peter Salovey and Mayer jack, creator of the term "emotional intelligence", described it as, "the ability to recognize feelings, reach and awaken your senses to help thoughts, feelings and understand its meaning and feeling deeply handle up to assist the development of 
emotional and intellectual." (Stein \& Book, 2002). In other words EQ is a series of intelligence that allows us to enlarge the complexities of the world in terms of personal, social and defense of all intelligence, common sense is enigmatic and sensitivity are important for the effective functioning of every day. Goleman discussed many research studies showing that a person's IQ predicts only small part of career performance-ranging from 4 to 20 percent. But recent studies have shown that emotional intellegince predicts about 80 percent of a person's success in life (Pool, 1997).

According to Casey and Cob IQ (Intelligence Quotient) high can backfire if EI (Emotional Intelligence) is not offset. To utilize or develop cognitive intelligence reached its peak, were initially required adequate emotional intelligence, the higher a person's emotional intelligence, the higher the person's ability to self-mangement behavior in the environmental. The higher a person's emotional intelligence, the greater the likelihood for success as workers, parents, managers, parents of a child for us, although for our spouse or a candidate for a position in the department, emotional intelligence or high EQ Emotional Intelligence (Cobb \& Mayer, 2000).

Emotional intelligence helps and guides the mind and curiosity, makes us think about how to avoid the dangers of anger it helps us to overcome divisions to get what we need and we can find happiness with someone else.

\subsection{School Principal Performance}

According Weterman and Donoghue (2000), the meaning of a person's overall performance is the ability to work in such a way so as to achieve the purpose of working optimally. Opinion is almost consistent with those presented by Winardi that the performance level of a job is done until the objectives are achieved (Winardi, 1990).

The school principal is one of the most educational components plays that a role in improving the quality of education. As Supriadi (1998) that: "Closely related to the quality of school principals with various aspects of school life such as school discipline, school culture atmosphere, and declining student naughty behavior".

According to Kamaruddin Husein (1994), the ability to improve the quality of teaching and learning is an important criteria for a school principal. High quality education can only be achieved if teachers and education administrators have the dedication and commitment to their educational task.

According to Griffin (1987), performance is determined by three things: ability, motivation and environment. Enviroment is proper methodology, materials and tools to do the job. Dessier (1992), said the performance should be evaluated. The reason are: (a) provide information as a basis for making decisions about promotions and salaries, (b) Provide an opportunity for an accomplice to jointly review the behavior of an accomplice in connection with his work.

According to Alan and Baker (1991), performance criterias are 1) development, 2) working group, 3) communication, 4) the amount of product produced and 5) decision. Cherrington (1995) says that accomplice evaluated on; productivity, accidents at work, being absent without permission, errors and overall work performance. Performance appraisal is very important to know the abilities of labor compared with the requirements of the current job or in the future.

Rivai (2005) noted a study conducted by Laze and Wikstrom about factors work performance is rated by 125 companies in the United States were included in the common factors that have similarities in 61 companies including: understanding of the job, leadership, initiative, quality of work, teamwork, decision making, creativity, unmatched, planning, communications, intelligence, problem solving, delegation, attitude, effort, motivation and organization.

As a determinant of the direction and goals of the organization, leaders must have a vision and mission. According Rahimah et al. (1999) which confirms the principals in the school's mission and vision of the school are considered as effective as principals in effective school that has a strong commitment and strive to achieve the vision and mission and encourage high-quality work ethic and accountability among staff. In setting the vision and mission, leaders must set goals, pointing in the direction of movement in the right direction and ordered to continue working. Through the vision and mission leaders instill and develop the discipline and working environment.

According to Hussein Ahmad (1991), school leadership needs to have a vision and mission to enhance understanding and skills in science and technology with more creative. Effective principals indicated that their behavior is more focused on school goals. According to Owens (2001), leader of the work with his followers to achieve is not only the goals to be achieved by the leader but also his goal in General. 


\section{Research Methods}

The method used in this research is quantitative method. Kerlinger (1993) noted the most appropriate quantitative survey method was used to examine the relationship of the dependent variable. The study designed to evaluate the performance of school principals, school-based management of understanding, emotional intelligence. A descriptive design was used to obtain a clear picture of the mean, and standard deviation. The study will also determine the mutual relationship between emotional intelligence and school-based management of understanding with the principal's performance of Senior Islamic School, using statistical analysis Pearson correlation and linear regression.

Correlation method Shows the person correlation coefficient $r$-shaped either positive $(+)$ or negative $(-)$ to indicate the interactions between variables. Coefficient values between 0.00 and 1.00 also mean the strength of the relationship. Recommendation "rule of thumb" by Johnson and Nelson (1986) used to describe the strength of correlation no correlation (0.00); very low; low; simple; very high and perfect relationship (1.00).

Collecting data through questionnaires. In quantitative methods Békés one way to get information from the respondents are using a questionnaire (Tucker et al., 1978). The questionnaire covers a wide area that can be designed easily and without the presence of researchers (Rubin \& Babbie, 2001). 5 points Likert scales used to indicate the level of frequency that things happen and vice versa for each statement submitted (Cavanagh, 2005).

This study uses three sets of questionnaires covering aspects contained in the conceptual framework. Instrument performance is attributed to a religious school principal instruments used the questionnaire "Principal Intructional Management Rating Scale" (PIMRS) by Hallinger and Murphy (1987) according to the suitability of the research questions. Additional items borrowed from the model Krug (1992) associated correlated to leadership lessons that have been modified by the researcher. Performance of school principals questionnaire consists of 40 items religions, which include a clear mission, vision and goals of the school 6 items, managing curriculum and instruction 6 item, supervise teaching and learning 6 item, item 6 observing student progress, teaching and learning climate encourages 6 items, staff development/professional development 5 items and collaborations with external parties 5 items.

Questionnaire adopted school-based management understanding of the instruments have been adopted by YC Cheng (1993) and understanding of school-based management consists of 32 items, it includes three items of understanding the mission of the school, 11 items of understanding on strategic management, 6 items of understanding the decision-making style, 4 items to understand and use of resources, 5 items to understanding the different roles, 3 items to the understanding of the quality of administration.

Principal emotional intelligence questionnaire is a questionnaire EQ-i, of the Bar-On (2000), which contains 60 items to measure emotions include intrapersonal and interpersonal, adjustment and pressure monitoring. Instruments interpersonal component has 6 items, 12 items in the components of intrapersonal, 12 items in the pressure adjustment components and 10 items in the ability to control pressure. In addition to a scale of emotional intelligence, EQ-I of the Bar-On also has 14 items in the ability roles and 6 items in the components of the validity of a positive response. Studies were conducted in eight districts or cities including Banten province. To ensure a smooth process of collecting data, this study held in eight regencies or cities Banten province, namely: Kota Tangerang, South Tangerang, Tangerang, Serang, Serang, Pandeglang, Lebak and Cilegon.

The population in this study is a teacher at a religious school State Banten. The overall population 180 people in four counties and three cities in the state Banten will be involved in this research study. Sampling is done by using the technique of "random sampling". Random sampling method is a method used to select the sample of the population in such a way so that every member of the population has an equal chance to be taken as a sample (Sugiyarto, 2003).

\section{Research Results}

\subsection{Descriptive Methods}

More descriptive statistical methods relate to the collection and summarization of data, as well as the presentation of the summary data. Descriptive statistical is used in order to answer the research question understanding of school-based management, emotional intelligence and performance levels Religious High School Principal. The results of the study method can be seen in Table 1 . 
Table 1. Results of the study by using descriptive method

\begin{tabular}{|c|c|c|c|c|c|}
\hline \multirow{3}{*}{$\begin{array}{l}\text { No } \\
1\end{array}$} & \multirow{3}{*}{$\begin{array}{l}\text { Variable } \\
\text { Performance of } \\
\text { the principal }\end{array}$} & \multicolumn{2}{|c|}{ Dimention } & \multirow{2}{*}{$\begin{array}{l}\text { Mean } \\
3.27\end{array}$} & \multirow{2}{*}{$\begin{array}{l}\text { Standard Deviation } \\
0.92\end{array}$} \\
\hline & & 1 & Explain, vision, mission and goals of the school & & \\
\hline & & 2 & $\begin{array}{l}\text { Explain, Managing curriculum and learning } \\
\text { vision, mission and goals of the school }\end{array}$ & 3.38 & 0.91 \\
\hline & & 4 & Monitor student progress & 3.39 & 0.87 \\
\hline & & 5 & Promote the teaching and learning climate & 3.33 & 0.89 \\
\hline & & 6 & The development of staff / professional teacher & 3.32 & 0.91 \\
\hline & & 7 & Cooperation with external parties & 3.89 & 1,29 \\
\hline & & \multicolumn{2}{|c|}{ Performance of the Principal } & 3.33 & 0.96 \\
\hline \multirow[t]{7}{*}{2} & \multirow{7}{*}{$\begin{array}{l}\text { Understanding } \\
\text { of school-based } \\
\text { management }\end{array}$} & 1 & Mission schools & 3.54 & 0.98 \\
\hline & & 2 & Strategic management & 3.62 & 1.02 \\
\hline & & 3 & Style of decision-making & 3.63 & 0.99 \\
\hline & & 4 & Use of resources & 3.61 & 0.97 \\
\hline & & 5 & Different roles & 3.67 & 0.91 \\
\hline & & 6 & Quality administration & 3.55 & 0.88 \\
\hline & & & erstanding of school-based management & 3.61 & 1.00 \\
\hline \multirow[t]{7}{*}{3} & \multirow{7}{*}{$\begin{array}{l}\text { Emotional } \\
\text { Intelligence }\end{array}$} & 1 & Intrapersonal & 3.33 & 0.99 \\
\hline & & 2 & Interpersonal & 3.52 & 0.91 \\
\hline & & 3 & Pressure adjustment & 3.42 & 0.90 \\
\hline & & 4 & Pressure monitoring capabilities & 3.24 & 0.88 \\
\hline & & 5 & Ability role & 3.26 & 0.88 \\
\hline & & 6 & Validity of positive responses & 3.23 & 0.88 \\
\hline & & \multicolumn{2}{|c|}{ Emotional Intelligence } & 3.34 & 1.02 \\
\hline
\end{tabular}

Table 1. It can be known from the overall high school principals' performance shown by respondents moderately high for the group to explain the vision. Mission and goals moderately high school (mean=3.27, standard deviation=0.92), group managing curriculum and instruction moderately high (mean $=3.38$, standard deviation $=0.91$ ), the group oversees the teaching and learning moderately high (mean $=3.34$, standard deviation $=0.89$ ), monitor student progress moderately high (mean $=3.39$, standard deviation $=0.87$ ), managing teaching and learning climate moderately high (mean $=3.33$, standard deviation=0.89), staff development/professional teacher moderately high (mean $=3.32$, standard deviation $=0.91$ ), in cooperation with external parties moderately high (mean $=2.89$, standard deviation=1.29) and Performance of the Principal is moderately high (mean $=3.33$, standard deviation $=0.96$ ).

Overall understanding of school-based management is shown by respondents moderately high for the group understanding simple mission high school (mean=3.54, standard deviation $=0.98$ ), the group's strategic management understanding moderately high (mean $=3.62$, standard deviation=1.02), group style decision making moderately high (mean $=3.63$, standard deviation $=0.99$ ), moderately high use of resources ( mean $=3.61$, standard deviation=0.97), the role of different groups of moderately high (mean=3.67, standard deviation=0.91), a group of quality moderately high administration (mean $=3.55$, standard deviation $=0.88$ ), and perception of school principals based management overall is moderately high (mean $=3.61$, standard deviation $=1.00$ ).

A descriptive study findings show that emotional intelligence principals in the School of Religion SMA Banten seen in table 1. It was found that the group with moderately high intrapersonal (mean $=3.33$, standard deviation $=0.99$ ); interpersonal group with moderately high (mean $=3.52$, standard deviation=0.91); group pressure adjustment with moderately high (mean $=3.42$, standard deviation $=0.90$ ); group supervision capabilities with moderately high pressure (mean $=3.24$, standard deviation $=0.88$ ), the simple role of high ability group (mean $=3.26$, standard deviation $=0.88$ ); and the validity of the responses to the group with moderately high 
positive (mean $=3.23$, standard deviation $=0.88$ ); and overall emotional intelligence principals with moderately high ( mean $=3.34$, standard deviation=1.02).

\subsection{Inferential Methods}

\subsubsection{Product Moment Correlation Analysis}

4.2.1.1 Understanding the Relationship with the School-Based Management Performance Religious School Principal.

Retrieved information from questionnaires on understanding school-based management and performance Upper Secondary Religious School principals werw answered by 180 respondents, with Pearson correlation analysis. The findings of understanding of the relationship between school-based management with performance Religious School principals is outlined in Table 2.

Tabel 2. Understanding the relationship between school-based management with performance religious school principals

\begin{tabular}{|c|c|c|c|c|c|c|c|c|}
\hline $\begin{array}{l}\text { School Principal } \\
\text { Performance } \\
\text { Perception } \\
\text { Management } \\
\text { School-based }\end{array}$ & $\begin{array}{l}\text { Describes the } \\
\text { vision, mission } \\
\text { and goals } \\
\text { school }\end{array}$ & $\begin{array}{l}\text { Care of } \\
\text { Curriculum } \\
\text { and Learning }\end{array}$ & $\begin{array}{l}\text { Supervise } \\
\text { Teaching and } \\
\text { Learning }\end{array}$ & $\begin{array}{l}\text { Monitor } \\
\text { Student } \\
\text { Progress }\end{array}$ & $\begin{array}{l}\text { Promoting } \\
\text { Teaching and } \\
\text { Learning } \\
\text { Climate }\end{array}$ & $\begin{array}{l}\text { Development } \\
\text { Professional } \\
\text { Staff/Profesional } \\
\text { Teachers }\end{array}$ & $\begin{array}{l}\text { Cooperation } \\
\text { with Foreign } \\
\text { Parties }\end{array}$ & $\begin{array}{l}\text { Religious } \\
\text { School } \\
\text { Principal } \\
\text { Performance }\end{array}$ \\
\hline mission Schools & $.326^{* *}$ & $.464^{* *}$ & $.423^{* *}$ & $.483^{* *}$ & $.393^{* *}$ & $.427^{* *}$ & $.360^{* *}$ & $.621^{* *}$ \\
\hline $\begin{array}{l}\text { Strategic } \\
\text { Management }\end{array}$ & $.228^{* *}$ & $.253^{* *}$ & $.189^{*}$ & $.214^{* *}$ & $.186^{*}$ & $.365^{* *}$ & $.319^{* *}$ & $.369^{* *}$ \\
\hline $\begin{array}{l}\text { Decision-making } \\
\text { styles }\end{array}$ & $.261^{* *}$ & $.340^{* *}$ & $.307^{* *}$ & $.320^{* *}$ & $.291^{* *}$ & $.271^{* *}$ & $.261^{* *}$ & $.444^{* *}$ \\
\hline Use of resources & $.348^{* *}$ & $.299^{* *}$ & $.346^{* *}$ & $.337^{* *}$ & $.325^{* *}$ & $.202^{* *}$ & .106 & $.431^{* *}$ \\
\hline Different roles & $.259^{* *}$ & $.270^{* *}$ & $.279^{* *}$ & $.344^{* *}$ & $.278^{* *}$ & $.367^{* *}$ & $.215^{* *}$ & $.432^{* *}$ \\
\hline $\begin{array}{l}\text { quality } \\
\text { administration }\end{array}$ & $.155^{*}$ & $.396^{* *}$ & $.340^{* *}$ & $.409^{* *}$ & $.279^{* *}$ & $.291^{* *}$ & $.281^{* *}$ & $.467^{* *}$ \\
\hline $\begin{array}{l}\text { Understanding } \\
\text { Berasasakan } \\
\text { Management } \\
\text { School }\end{array}$ & $.326^{* *}$ & $.464^{* *}$ & $.423^{* *}$ & $.483^{* *}$ & $.393^{* *}$ & $.427^{* *}$ & $.360^{* *}$ & $.704^{* *}$ \\
\hline
\end{tabular}

Note. * significant at the level of $\mathrm{p}<0.05$

$* *$ significant at the level of $\mathrm{p}<0.01$

Based on the results in Table 2 above, a significant relationship was found to exist and sturdy at the level of $p<0.05$ between the management school based with religious school principals performance $(r=0.704 ; p<0.05)$ in the School of Religion Banten. Next, while understanding school-based management with group describes the vision, mission and goals of the school $(\mathrm{r}=0.326 ; \mathrm{p}<0.05)$, group managing curriculum and learning $(\mathrm{r}=0.464$; $\mathrm{p}<0.05)$, the group supervise teaching and learning $(\mathrm{r}=0.423 ; \mathrm{p}<0.05)$, the group monitors the progress of students $(\mathrm{r}=0.483 ; \mathrm{p}<0.05)$, a group promoting the teaching and learning climate $(\mathrm{r}=0.393 ; \mathrm{p}<0.05)$, groups of staff development or professional teacher $(\mathrm{r}=0.427 ; \mathrm{p}<0.05)$ and group collaborations with external parties $(\mathrm{r}=0.360 ; \mathrm{p}<0.05)$.

The next strategic management group with religious school principal performance $(r=0.369 ; \mathrm{p}<0.05)$, the group describes the vision, mission and goals of the school $(\mathrm{r}=0.228 ; \mathrm{p}<0.05)$, group managing curriculum and learning $(\mathrm{r}=0.253 ; \mathrm{p}<0.05)$, group supervise teaching and learning $(\mathrm{r}=0.189 ; \mathrm{p}<0.05)$, the group monitors the progress of students $(\mathrm{r}=0.214 ; \mathrm{p}<0.05)$, a group promoting the teaching and learning climate $(\mathrm{r}=0.186 ; \mathrm{p}<0.05)$, group development staff or professional teacher $(\mathrm{r}=0.365 ; \mathrm{p}<0.05)$, and group collaboration with outside parties $(\mathrm{r}=0.319 ; \mathrm{p}<0.05)$.

The next group decision making styles with the religious schools principals' performance $(0.444, \mathrm{p}<0.05)$, the 
group describes the vision, mission and goals of the school $(\mathrm{r}=0.261 ; \mathrm{p}<0.05)$, group managing curriculum and learning $(r=0.340 ; p<0.05)$, group supervise teaching and learning $(r=0.307 ; p<0.05)$, the group monitors the progress of students $(r=0.320 ; p<0.05)$, a group promoting the teaching and learning climate $(r=0.291 ; p<0.05)$, groups of staff development or professional teacher $(\mathrm{r}=0.271 ; \mathrm{p}<0.05)$, and group collaborations with external parties $(\mathrm{r}=0.261 ; \mathrm{p}<0.05)$.

The next group of resource used and the achievement of Religious School principals $(r=0.431 ; p<0.05)$, the group describes the vision, mission and goals of the school $(\mathrm{r}=0.348 ; \mathrm{p}<0.05)$, group managing curriculum and learning $(r=0.299 ; p<0.05)$, the group oversees the teaching and learning $(r=0346 ; p<0.05)$, the group monitors the progress of students $(\mathrm{r}=0.337 ; \mathrm{p}<0.05)$, a group promoting the teaching and learning climate $(\mathrm{r}=0.325$; $\mathrm{p}<0.05)$, groups of staff development or professional teacher $(\mathrm{r}=0.202 ; \mathrm{p}<0.05)$, and group collaborations with external parties $(\mathrm{r}=0.106 ; \mathrm{p}<0.05)$.

The next group of different roles with the performance of principals Religious School $(r=0.432 ; p<0.05)$, the group describes the vision, mission and goals of the school $(\mathrm{r}=0.259 ; \mathrm{p}<0.05)$, group managing curriculum and learning $(r=0.270 ; p<0.05)$, the group oversees the teaching and learning $(r=0.279 ; p<0.05)$, the group monitors the progress of students $(\mathrm{r}=0.344 ; \mathrm{p}<0.05)$, a group promoting the teaching and learning climate $(\mathrm{r}=0.278$; $\mathrm{p}<0.05)$, groups of staff development or professional teacher $(\mathrm{r}=0.367 ; \mathrm{p}<0.05)$, and group collaborations with external parties $(\mathrm{r}=0.215 ; \mathrm{p}<0.05)$.

The next group of quality administrators with performance principals Religious School $(r=0.467 ; \mathrm{p}<0.05)$, the group describes the vision, mission and goals of the school $(\mathrm{r}=0.155 ; \mathrm{p}<0.05)$, group managing curriculum and learning $(r=0.396 ; p<0.05)$, the group supervise the teaching and learning $(r=0.340 ; p<0.05)$, the group monitors the progress of students $(\mathrm{r}=0.409 ; \mathrm{p}<0.05)$, a group promoting the teaching and learning climate $(\mathrm{r}=0.279$; $\mathrm{p}<0.05)$, group staff development or professional teacher $(\mathrm{r}=0.291 ; \mathrm{p}<0.05)$, and group collaborations with external parties $(\mathrm{r}=0.281 ; \mathrm{p}<0.05)$.

\subsubsection{Relationship between Emotional Intelligence and Performance with High School Principal Religion}

Retrieved information from questionnaires emotional intelligence and performance religious school principals were answered by 180 respondents, with person correlation analysis. The findings that correlation between emotional intelligence and performance religious school principals SMA show on Table 3.

Table 3. The relationship between emotional intelligence and school principals' performance

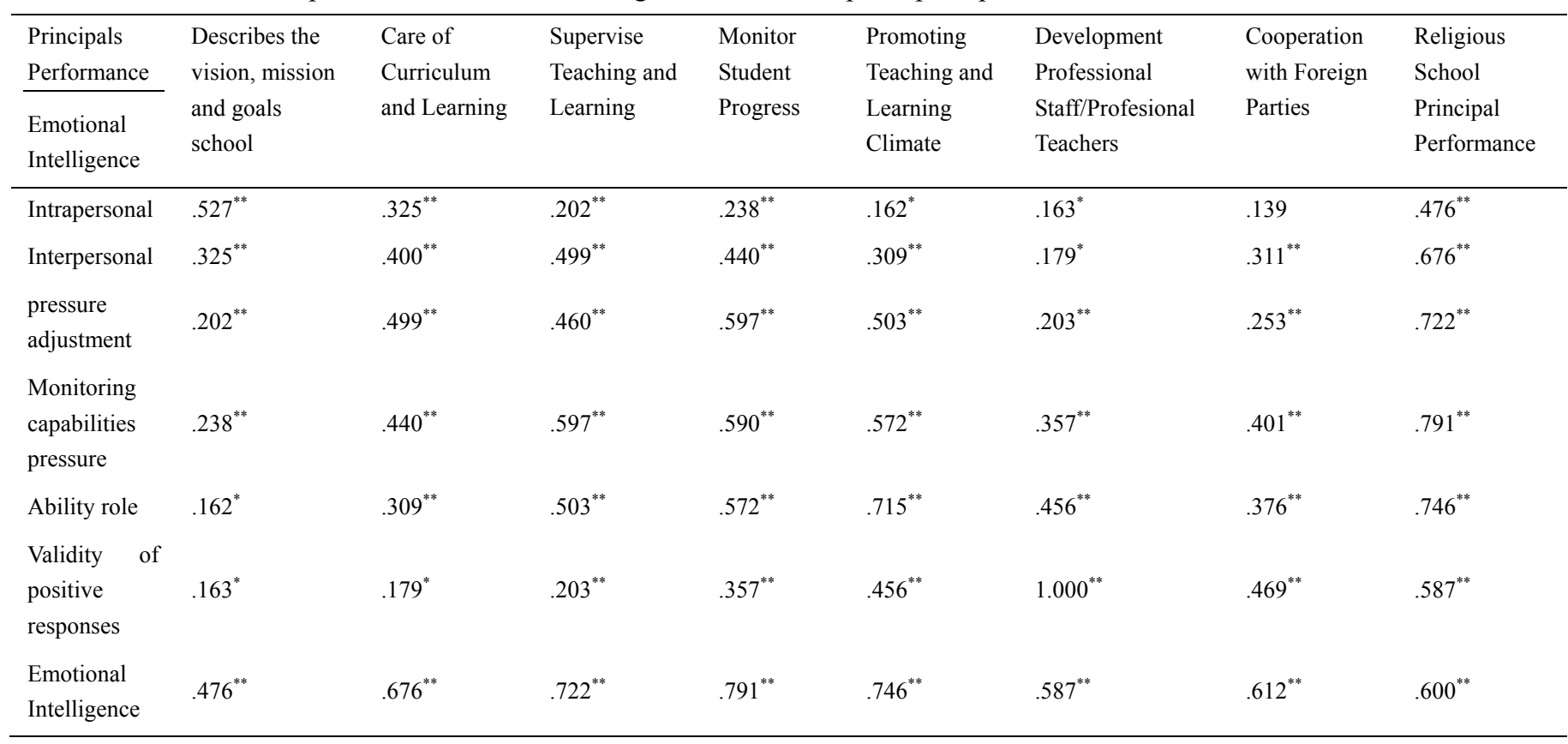

Note. * Significant at level $\mathrm{p}<0.05$ 
Based on the results in Table 3 above, a significant relationship was found to exist and sturdy at the level of $p<0.05$ between emotional intelligence and performance Religious School principals $(r=0.600 ; p<0.05)$ in the School of Religion. While the relationship with the group's vision, mission and goals of the school $(\mathrm{r}=0.476$; $\mathrm{p}<0.05)$, group managing curriculum and learning $(\mathrm{r}=0.676 ; \mathrm{p}<0.05)$, the group oversees the teaching and learning $(\mathrm{r}=0.722 ; \mathrm{p}<0.05)$, the group monitors the progress of students $(\mathrm{r}=0.791 ; \mathrm{p}<0.05)$, a group promoting the teaching and learning climate $(\mathrm{r}=0.746 ; \mathrm{p}<0.05)$, groups of staff development or professional teacher $(\mathrm{r}=0.587 ; \mathrm{p}<0.05)$, and in collaboration with outsiders $(\mathrm{r}=0.612, \mathrm{p}<0.05)$.

There intrapersonal group with a religious school principals performance $(r=0.476 ; p<0.05)$, the group describes the vision, mission and goals of the school $(\mathrm{r}=0.527 ; \mathrm{p}<0.05)$, group managing curriculum and learning $(\mathrm{r}=0.325$; $\mathrm{p}<0.05)$, the group supervise the teaching and learning $(\mathrm{r}=0.202 ; \mathrm{p}<0.05)$, the group monitors the progress of students $(\mathrm{r}=0.238 ; \mathrm{p}<0.05)$, a group promoting the teaching and learning climate $(\mathrm{r}=0.162 ; \mathrm{p}<0.05)$, groups of staff development or professional teacher $(\mathrm{r}=0.163 ; \mathrm{p}<0.05)$ and group collaborations with external parties $(\mathrm{r}=0.139 ; \mathrm{p}<0.05)$.

The next group of interpersonal performance principals Religious School ( $r=0.676 ; p<0.05)$, the group describes the vision, mission and goals of the school $(\mathrm{r}=0.325 ; \mathrm{p}<0.05)$, group managing curriculum and learning $(\mathrm{r}=0.400$; $\mathrm{p}<0.05)$, the group oversees the teaching and learning $(\mathrm{r}=0.499 ; \mathrm{p}<0.05)$, the group monitors the progress of students $(\mathrm{r}=0440 ; \mathrm{p}<0.05)$, a group promoting the teaching and learning climate $(\mathrm{r}=0.309 ; \mathrm{p}<0.05)$, group staff development/professional teacher $(\mathrm{r}=0.179 ; \mathrm{p}<0.05)$, and group collaborations with external parties $(\mathrm{r}=0.311$, $\mathrm{p}<0.05)$.

The next group with pressure adjustment Religious School principals performance $(r=0.722 ; \mathrm{p}<0.05)$, the group describes the vision, mission and goals of the school $(r=0.202 ; \mathrm{p}<0.05)$, group managing curriculum and learning $(\mathrm{r}=0.499 ; \mathrm{p}<0.05)$, the group oversees the teaching and learning $(\mathrm{r}=0.460 ; \mathrm{p}<0.05)$, the group monitors the progress of students $(\mathrm{r}=0.597 ; \mathrm{p}<0.05)$, a group promoting the teaching and learning climate $(\mathrm{r}=0.503 ; \mathrm{p}<0.05)$, group staff development/professional teacher $(\mathrm{r}=0.203 ; \mathrm{p}<0.05)$, and group collaborations with external parties $(\mathrm{r}=0.253 ; \mathrm{p}<0.05)$.

The next group pressure monitoring with performance capabilities Religious School principals $(r=0.791 ; p<0.05)$, the group describes the vision, mission and goals of the school $(\mathrm{r}=0.238 ; \mathrm{p}<0.05)$, group managing curriculum and learning $(\mathrm{r}=0.440 ; \mathrm{p}<0.05)$, the group oversees the teaching and learning $(\mathrm{r}=0.597 ; \mathrm{p}<0.05)$, the group monitors the progress of students $(\mathrm{r}=0.590 ; \mathrm{p}<0.05)$, a group promoting the teaching and learning climate $(\mathrm{r}=0.572 ; \mathrm{p}<0.05)$, groups of staff development/professional teacher $(\mathrm{r}=0.357 ; \mathrm{p}<0.05)$, and group collaborations with external parties $(\mathrm{r}=0.401 ; \mathrm{p}<0.05)$.

The next group with the performance capabilities of the role of school principals Religion $(r=0.746 ; p<0.05)$ groups to explain the vision, mission and goals of the school ( $\mathrm{r}=0.162 ; \mathrm{p}<0.05)$, group managing curriculum and learning $(r=0.309 ; p<0.05)$, the group oversees the teaching and learning $(r=0.503 ; p<0.05)$, the group monitors the progress of students $(\mathrm{r}=0.572 ; \mathrm{p}<0.05)$, a group promoting the teaching and learning climate $(\mathrm{r}=0.715$; $\mathrm{p}<0.05)$, group development staff/professional teacher $(\mathrm{r}=0.456 ; \mathrm{p}<0.05)$, and group cooperation primarily to external parties $(r=0.376 ; \mathrm{p}<0.05)$.

The next group responded positively to the performance of the validity of the principal of Religion $(\mathrm{r}=0.587$; $\mathrm{p}<0.05)$, the group describes the vision, mission and goals of the school $(\mathrm{r}=0.163 ; \mathrm{p}<0.05)$, group managing curriculum and learning $(r=0.179 ; p<0.05)$, the group oversees the teaching and learning $(r=0.203 ; p<0.05)$, the group monitors the progress of students $(\mathrm{r}=0.357 ; \mathrm{p}<0.05)$, a group promoting the teaching and learning climate $(\mathrm{r}=0.456 ; \mathrm{p}<0.05)$, groups of staff development/professional teacher $(\mathrm{r}=0.420 ; \mathrm{p}<0.05)$, and group collaborations with external parties $(r=469 ; \mathrm{p}<0.05)$.

\subsubsection{Multiple Regression Analysis}

There is a relationship between the Supervisory Principal and Emotional Intelligence Taken together with the Religious School Principal Performance.

The next question is a relationship between the perception of school-based management (school's mission, strategic management, decision-making styles, use of resources, a different role, the quality of administration) and emotional intelligence (intrapersonal, adjustment pressure, pressure monitoring capability, ability and validity role posisitf response) together with the performance of the Religious School principals. Multiple regression analysis was used to demonstrate the interaction index by referring to the beta $(\beta)$, which can be seen in Table 4. 
Table 4. Understand the relationship between school-based management and emotional intelligence along with School Principal Performance

\begin{tabular}{|c|c|c|c|c|}
\hline $\begin{array}{l}\text { Understanding factors and Schoo } \\
\text { Management Emotional Intelligence }\end{array}$ & B & $\operatorname{Beta}(\beta)$ & Nilai T & Sig \\
\hline Strategic Management & 1.155 & .261 & 15.97 & .000 \\
\hline Use of Resources & 1.138 & .265 & 18.70 & .000 \\
\hline Administration of quality & 1.067 & .261 & 16.68 & .000 \\
\hline Validity of Positive Feedback & 1.338 & .252 & 18.85 & .000 \\
\hline intrapersonal & 981 & .202 & 16.21 & .000 \\
\hline Pressure adjustment & .0950 & 211 & 13.28 & .000 \\
\hline
\end{tabular}

Note. $*$ at the significance level $\mathrm{p}<0.05, \mathrm{R}=0.988 \mathrm{R}$ multiple $=0.976$

Multiple regression analysis through Table 4 from the table above, shows that the understanding the relationship between school-based management and emotional intelligence along with School Principal Performance at significant level $\mathrm{p}<0.05$. The value of beta $(\beta)$ between the performance of SMA Religious School principals with strategic management is $(\beta=0.261 ; \mathrm{t}=15.97 ; \mathrm{Sig}=0.000)$. The formula is a factor of strategic management is to act as a cause or predictor of performance in Upper Secondary Religious School principals, which means understanding the strategic management factors linked to the performance of religious school principals.

Multiple regression analysis through Table 4 demonstrate understanding of resource utilization factor has a significant relationship with the level of $p<0.05$. The value of beta $(\beta)$ between the performance of principals Religious School with is $(\beta=0.265 ; \mathrm{t}=18.71 ; \mathrm{Sig}=0.000)$. The formula to understand of resource use is as a cause or contribute to the performance of permal Religious School principals, which means the use of understanding use of resources linked to the performance of a religious school principals.

Multiple regression analysis through Table 4 demonstrate an understanding of factors linked to the quality of administrative performance Upper Secondary Religious School principals at significant level $p<0.05$. The value of beta $(\beta)$ between the performance of principals Religious School with is $(\beta=0.261 ; t=16.68 ; \mathrm{Sig}=0.001)$. The formula to understand the quality of administration is a factor plays a role as a cause or predictor of performance in Upper Secondary Religious School principals, which means the perception of the quality of the administration have a relationship with the performance of Religion High School principal.

Multiple regression analysis through Table 4 demonstrate the validity of the positive responsefactors have a relationship with a religious school principals performance at significant level $p<0.05$. The value of beta $(\beta)$ between the performance of principals Religious School with is $(\beta=0.252 ; \mathrm{t}=18.85$; $\mathrm{Sig}=0.001)$. The formula is the factor validity posotif response is act as the cause or predictor of performance in Upper Secondary Religious School principals, which means the validity respond positively linked to the performance of religious school principals.

Multiple regression analysis through Table 4 demonstrate intrapersonal factors linked to the performance of a religious school principals at significant level $p<0.05$. The value of beta $(\beta)$ between the performance of principals Religious School with is $(\beta=0.202 ; \mathrm{t}=16.21 ; \mathrm{Sig}=0.000)$. The formula is intrapersonal factors are instrumental as a cause or Permal's performance Religious School principals, which means intrapersonal factors have a relationship with performance Religious School principals.

Multiple regression analysis with adjustment factors in Table 4 . Show pressure has a relationship with a religious school principals performance at significant level $\mathrm{p}<0.05$. The value of beta $(\beta)$ between the performance of principals Religious School with is $(\beta=0.211 ; \mathrm{t}=13.29 ; \mathrm{Sig}=0.000)$. The formula is pressure adjustment factor is to act as a cause against of the principal achievement in high school religious, this means that of pressure adjustment factor has a relationship with the achievement of the principal at the High School of Religion.

\section{Discussion}

From the research found that the performance of the sub school principals are the highest in the school council is to monitor the progress of students, followed by sub managing curriculum and instruction, supervision of teaching and learning, encourage a climate of teaching and learning, staff development, describes the vision, mission and goals of the school and collaboration with external parties, but as a whole the performance of school 
principals in schools religion is moderately high. The above findings are based on Terry (1983) there are 20 ways of leadership tasks are: 1) setting the vision and mission, 2) set value, 3) create value, 4) motivate, 5) manage, 6) the unity of the work, 7) to give explanation, 8) symbol service, 9) representative group, and 10) reformer.

Understanding of the results-based management of schools with the highest sub looks different roles, followed by the style of decision making, strategic management, resource use, quality of administration and the school's mission, but overall the understanding of school-based management is moderately high. The above findings differ from the study Rahmat Syukor Abd. Samad (2003) in Malaysia, which shows the implementation of school-based management in Petaling District is high.

The findings indicate that principals School Religion in Banten Province has a moderately high emotional intelligence to intrapersonal, interpersonal, validity and positive feedback for pressure adjustment, and the ability to play. Owned emotional intelligence is a part of the competencies required to principals that social competence, social competence is where the principals' ability to communicate and interact effectively with students, fellow educators, parents/guardians of students, and surrounding communities (Directorate General of Higher Education and Workforce Directorate of Professional Education Ministry's Directorate General of Quality Improvement). Leaders can capture emotion and attitude, it will be easier to interact, less aggressive, more than happy to help others, make constructive comments and take action to improve teachers' job satisfaction (Noran \& Sharifah, 1990).

Through product moment correlation analysis, the results showed that there is a relationship of understanding with the performance of school-based management principals of Religious school. The relationship was seen between school-based management of all sub-based management school with all sub performance in religious school principals. Understanding of school-based management has a relationship with the group describes the vision, mission and objectives of the school, the curriculum and teaching management, the group oversees the teaching and learning, group monitoring student progress, climate encourages learning, staff development/professional teachers and in cooperation with external parties. In other words understanding of school-based management has a strong influence in increasing performance principal, a school principal can not ignore the ability of school-based management in understanding when the desire for self-improvement of performance.

In the case of school-based management is the application of the principals that can formulate, explain and actualize, mission schools, performing the functions of strategic management, development various styles in decision-making, resource use, has the quality of governance, and provide role played by each element in school (Rahmad, 1997). Results of research conducted by Cheng (1996), Sergiovani (2001), school-based management has driven the need to improve the academic achievement of students and educational institutions to change for the better. Student achievement and school educational institution's performance is the performance of school principals.

There is a relationship between emotional intelligence and performance Upper Secondary Religious School principals. All subscales of emotional intelligence have a relationship with a sub-scale with the performance of Religion High School principal. While the relationship with the group's vision, mission and goals of the school, curriculum and learning care group, the group oversees the teaching and learning, student progress monitoring group, the group promotes the teaching and learning climate, group staff development or professional teachers, and cooperation with external parties.

Emotional intelligence helps and guides the mind and curiosity, makes us think about how to avoid the dangers of anger helps us to overcome obstacles to get what we need and we can find happiness in other people's togetherness. Emotional intelligence can basically be applied in a variety of places, situations, conditions and time. Emotional intelligence can be widely applied to work, study, teaching, parenting, amity, and households (Agus, 2003).

Based on the multiple regression analysis found that school-based management understanding and emotional intelligence together have a relationship and become predictor a performance of principals in Religion Upper Secondary School. The sequence relationship and as a predictor of first sub-scale strategic management, use of resources, the quality of the administrator, the ability development, pressure adjustment, dam validity of positive feedback can be a predictor of performance of principals in Religion Upper Secondary School.

School-based management (SBM) is a strategy to create an effective and productive school. The findings Rahmad Syukor Abd Samaf (2003) in Malaysia Petaling District shows that shows that schools implementing school-based management is characterized by several elements, namely: (1) trust for lifelong learning and continuous improvement development school, (2) teachers' professional development, (3) developing of staff 
and leadership, (4) the responsibility of every member of the school to achieve school goals and develop a school culture and mission of the school, (5) showing the level of leadership, as well as staff development model, and (6) the concept of how to improve student growth. According to Casey and Cob (2000) IQ (intelligence quetion) high can backfire if EI (emotional intelligence) does not compensate. To utilize or develop cognitive intelligence, emotional intelligence needed to peak adequate. The higher a person's emotional intelligence, the greater the likelihood for success as workers, parents, managers, adult children of our parents, partners for our spouse or a candidate for a position.

Performance principals and who are able to explain the vision and mission and goals of the school, managing curriculum and instruction, monitor student progress, supervise teaching and learning, encourage a climate of learning and teaching, and staff development or professional development, and collaboration with external parties that have been documented by Husein Mahmod (1997).

\section{Conclusion}

Understanding of school-based management and emotional intelligence has a considerable influence on the performance of school principals. The higher understanding of school-based management owned a principal, as well as having good emotional intelligence themselves, will have a considerable influence on the improvement of the performance of a school principal in school management. High school-based management understanding and moderately high levels of emotional intelligence, understanding the relationship between school-based management, emotional intelligence, and performance in a religious school principal Banten Province. Understanding the relationship between school-based management and emotional intelligence and performance Upper Secondary Religious School principals, and subscales understanding of school-based management and emotional intelligence can be a predictor of teacher competence Religious School Banten Province.

Understanding of school-based management will encourage principals to perform the duties as leader, manager, administrator, supervisor, innovator, and motivator. If the principal of a school-based management understanding about the possibility of achieving the goal of good faith schools as educational institutions that quality is difficult to achieve. Improved understanding of school-based can also be done independently by the school principal religion by reading the literature on school-based management and can also be done by organizing tours to other schools and see for yourself how the implementation of school-based management, followed by a dialogue.

Another factor that may support religious school principal performance is the improvement of emotional intelligence. Emotional intelligence is essentially concerned with the ability of self-consciousness principals foster knowledge what they feel, can take decisions independently, have the ability relaistis benchmark themselves, and have self-confidence. To enhance emotional intelligence principals obtained through the process of education and specialized training conducted continuously carried out by institutions that provide education and training in emotional intelligence and relevant agencies or particular institutions. Emotional intelligence principals can also be done independently by providing training and emotional control, social sensitivity training, through the practice of social values and religious communities. Emotional intelligence has a significant contribution to the achievement of the school principal, school principal religions will be able to manage with good emotional intelligence.

\section{References}

Abdul, K. M. N. (1989). Characteristic of effective rural secondary school in Malaysia (Dissertasi EdD.). USA: University of Winconsin, Madison.

Agus, N. (2003). Quantum Qoutient (Kecerdasar Quantum). Bandung: Penerbit Nuansa Cendekia, Cet. V.

Ahmad, H. B. H. (1991). Perkembangan Staf di Sekolah: Bentuk dan Cara Pelaksanaannya. Journal Pengurusan Pendidikan, 1(2). Institut Aminuddin Baki.

Alan, Anderson, H., \& Baker, D. (1991). Effective Enterprice and Change Management. Meassachusets: Blackwel Publisher, Ltd.

Awang, A., \& Dan Ramiah, B. A. (2002). Peranan pengetua dan guru besar dalam menentukan kecemerlangan akademik pelajar. Prosiding Seminar Nasional Pengurusan dan Kepimpinan Pendidikan ke-11. Institut Aminuddin Baki (Cawangan Utara). Kementerian Pendidikan Malaysia.

Bar-On, R. (2000). Emotional and social intelligence: Insights from the Emotional Quotient Inventory. In R. Bar-On, \& J. Parker (Eds.), The Handbook of Emotional Intelligence: Theory, Development, Assessment, and Application at Home, School, and in the Workplace (pp. 363-388). San Francisco, California: Jossey Bass Inc. 
Cavanagh, A. L. (2005). Introduction to Principalship. In J. Shen (Ed.), School Principals. New York: Peter Lang Publishing. Inc.

Cheng, Y. C. (1993). Profiles of organizational culture and effective schools. School Effectiveness and School Improvement, 4(2), 85-110. http://dx.doi.org/10.1080/0924345930040201

Cheng, Y. C. (1996). School Effectiveness \& School-based Management: A Mechanism for Development. London: The Falmer Press.

Cherrington, D. J. (1995). The Management of Human Resources (4th ed.). New Jersey: Prentice Hall Inc.

Covey, S. R. (2004). The 8th Habit: From Effectiveness to Greatness. London: Simon \& Schuster Publishing.

Dessler, G. (1992). Manajemen Sumber Daya Manusia. Jakarta: PT Prenhalindo.

Goleman, D. (1999). Ekonomi Entellegent. Gramedia Pustaka, Jakarta.

Goleman, D. (2005). Kecerdasan Emosi: Untuk Mencapai Puncak Prestasi. Terjemahan Alex Tri Kantjono. PT. Gramedia Pustaka Utama. Jakarta.

Goleman, D., Boyatzis, R., \& Mckee, A. (2004). Kepemimpinan berdasakan kecerdasan emosi. Jakarta: PT. Gramedia Pustaka Umum

Griffin, R. W. (1987). Management. Boston : Houghton Miffin.

Hallinger, P., \& Murphy, J. F. (1987). Principals Instructional Management. Educational Leadership, 45(1).

Hamlin, R. (2003). Towards a generic theory of managerial and leadership effectiveness: A meta-level analysis from organisations within the U.K. Public sector. In S. Lynham, \& T. Egan (Eds.), Proceedings of the Academy of Human Resource Development (pp. 944-951). Academy of Human Resource Development, Minneapolis, MN: Academy of Human Resource Development.

Husein, M. (1997). Kepemimpinan dan Keberkesanan Sekolah. Kuala Lumpur : Dewan Bahasa dan Pustaka.

Ishak, B. S. (2002). Gaya Kepimpinan Yang Digemari: Satu Kajian Kes-KesHipotetikal. Kertas kerja yang dibentangkan dalam Seminar Pengurusan danKepimpinan Pendidikan kali, ke-XI, 17-19. Sepang: Kuala Lumpur International Airport.

Johnson. B. L., \& Nelson, J. K. (1986). Practical Measurements for Evaluation in Physical Education. New York: Mac Millan Publishing Company.

Kamaruddin, H. (1994). Manajemen Berdasarkan Sasaran. Jakarta: Bumi Aksara.

Kerlinger, F. N. (1993). Asas-Asas Penelitian Behavioral. Edisi Indonesia, Yogyakarta: Gajah Mada University Press.

Krug, S. E. (1992). Instructional Leadership: A. Constructivist Perspective. Educational Administration Quarterly, 28(3). http://dx.doi.org/10.1177/0013161X92028003012

Lunenburg, F. C., \& Dan, O. (2004). Educational Administrasi: Concepts and Practices. Belmont USA: Wardworth.

Mayer, J. D., \& Cobb, C. D. (2000). Educational Policy on Emotional Intelligence: Does it Make Sense? Educational Psychology Review, 12.

Mohrman, W., \& Associaties. (1994). School Based Management: Organizing for High Peformance. San Francisco: Jossey Bass Pub.

Mulyasa, E. (2002). Manajemen Berbasis Sekolah. Bandung: Remaja Rosdakarya

Mulyasa, E. (2003a). Manajemen Berbasis Madrasah. Bandung: Remaja Rosdakarya.

Mulyasa, E. (2003b). Menjadi Kepala Sekolah Profesional: Dalam Konteks Menyukseskan MBS dan KBK. Bandung: Remaja Rosdakarya.

Noran, F. Y., \& Sharifah, M. N. (1990). Kepuasan Kerja Guru Di Dua Jenis Sekolah. Jurnal Psikologi Malaysia, $6,77-90$.

Owen, R. G. (2001). Organization Behavior in Education: Instructional Leadership and School Reform (7th ed.). Boston: Allyn and Bacon.

Pasiak, T. (2002). Revolusi IQ, EQ, SQ, Antara Neuro Sain,dan Al-Qur'an. Bandung: Mizan.

Pool, R. C. (1997). Up with emotional health. Educational Leadership Journal, 54. 
Rahimah, H. A., \& Zulkifli, A. M. (1999). Characteristic of effective andless effective schoolinRural and Urban setting: A case study from Malaysia. Paper presented at the 10th International Congress for school effectiveness and improvement (ICSE). Perbody, Memphis, Tennesee, USA.

Rahmad, S. A. (2003). Samad Pengajaran Berasaskan Masalah dalam Pendidikan Sains Sosial Abd. In R. A. Rashid (Ed.), Pengajaran dan Pembelajaran dalam Pendidikan Sains Sosial. Penerbit Universiti Malaya.

Rahmad, S. A. S., \& Yong, L. C. (2005). School-based Management: A Survey On The Extent Of Principals Knowledge And Implementation. Jurnal Pendidikan, 25.

Rahmad, S. A. S., \& Yong, L. C. (2005). School-based management: A survey on the Extent of Principals' Knowledge and Implementation. Journal of Educational Research, 25, 183-205.

Rahmad, S. A. S. (2005). Pengenalan Pendidikan Moral. Kuala Lumpur: OUM Press.

Rivai, V. (2005). Manajemen Sumber Daya Manusia untuk Perusahaan, dari Teori ke Praktik. PT. Raja Grafindo Persada, Jakarta.

Rubin, A., \& Babbie. (2001). Research Methods For Sosial Work (4th ed.). USA: Wadsworth/Thomson Leaming. Sergiovanni, T. J. (2001). The Principalship of reflektive Practice prespectif. Boston:Allyn and Bacon.

Stein, S. J., \& Book, H. E. (2002). Ledakan EQ: 15 Prinship Dasar kecerdasan Emosional Meraih Sukses. Alih Bahasa: Trinda Rainy Januarsari. Bandung: Kaifa.

Sugiarto. (2003). Teknik Sampling. Jakarta : PT. Gramedia Pustaka Utama.

Supriadi, D. (1998). Mengangkat Citra dan Martabat Guru. Yogyakarta: Adicita Karya Nusantara.

Terry, R. W. (1983). Authentic Leadership: Courage in Action. San Francisco: Inssey Bass Publisher.

Tucker, R. C. (1978). The Marx-Engels Reader (2nd ed.). New York: W. W. Norton \& Company.

Undang-undang Republik Indonesi Nomor 20 tahun 2003 tentang Sistem Pendidikan Nasional. (n.d.). Bandung: Citra Utama.

Weterman, J., \& Pauline, D. (2000). Pengelolaan Sumber Daya Manusia. Jakarta: Bumi Aksara.

Winardi. (1990). Asas-Asas Manajemen. Bandung: CV Mandar Maju.

Zehner, R., \& Holton, III. E. (2003). Development and validation of an instrument for early assessment of management potential. In S. Lynham, \& T. Egan (Eds.), Proceedings of the Academy of Human Resource Development (pp. 936-943). Academy of Human Resource Development. Minneapolis, MN: Academy of Human Resource Development.

\section{Copyrights}

Copyright for this article is retained by the author(s), with first publication rights granted to the journal.

This is an open-access article distributed under the terms and conditions of the Creative Commons Attribution license (http://creativecommons.org/licenses/by/3.0/). 